\title{
ROLE-PLAY IN TEACHING ENGLISH LITERATURE
}

\author{
Nisa Syuhda \\ UIN Sunan Kalijaga, Yogyakarta \\ Email: nisasyuhda@yahoo.co.id
}

\begin{abstract}
The important thing in teaching and learning process is teaching method. However, the teacher's creativity is more important than the method itself. This paper offers a method for EFL students to study English through literature. Role-play as a teaching method to increase students' linguistic competence through narrative as one of literary works. This paper also offers evaluation system to measure the students' competence in learning literature study through narratives of Hodja.
\end{abstract}

Keywords: Teacher's creativity, Literature as appropriation, Role-play rubric, Narratives of Hodja

\section{INTRODUCTION}

Teaching method is an art in transferring knowledge to the students. Sometimes it is regarded to be more significant than the material itself. Islamic adage states " $\mathrm{Al}$ thariqahahamm min al-maddah, wa al-mudarrisahamm min al-thariqah, war uh al-mudarrisahamm min almudarris" (Teaching method is more important than the materialsand the teacher is more important than the teaching method, and teacher's soul is more important than the teacher). In other way, this adage states that the most important in teaching and learning activities is teacher's creativity. It also expresses the reality that the communicative teaching method is more effectively understood by the students even though the material is not interesting. Otherwise, even though the material is good enough, it will not be understood by the students when the teaching method is not interesting. Therefore, applying appropriate method will affect the good result in teaching learning process.

There are some teaching learning methods can be applied to implement the teaching learning strategy. They are discussion, simulation, laboratory classes, field experience, and so on. The application of those methods should be chosen according to the materials. For EFL (English for Foreign Language) classes, it needs appropriate and effective teaching learning methods to avoid the failure.

The use of an inappropriate method can be an obstacle in English learning process. This can be seen from proficiencies of students graduated from high school in applying their practices in English as the foreign language. In Indonesia, English is learnt for more than six years, i.e. since elementary school. 
Many English learning materials which are ineffective or useless just because of the inappropriate learning method and only as desired by teachers - therefore, ignoring students' necessities, facilities and the existing situation and condition of the class.

In this paper, the writer discusses the role-play method which has an objective that the role-play method can be used as one of alternatives in English learning process as the foreign language for students by exposing the understanding of role-play method in teaching English as the foreign language, the application steps, and what materials that can be applied in this simulation method.

\section{LITERATURE REVIEW}

\section{The Nature of Literature}

\section{What is Literature}

Jonathan Culler (1997,p.28) asserts that "literature is not just a frame in which we put language .... on the other hand, literature is not a special kind of language, .... ; they function in special ways because of the special attention they receive." Furthermore, Culler (1997,p.28-34) takes up five points theorists have made about the nature of literature:

1. Literature as the 'foregrounding' of language "Literature is language that 'foregrounds' language itself" (Culler, 1997, p.28). Literature uses special organization of language, to make it different to or make it strange with other uses of language. The use of foregrounding language will make the reader cannot forget, because it formed in unusual ways. The reader will notice that they "are dealing with language organized to attract attention to the linguistic structures themselves" (Culler, 1997,p.29)

2. Literature as the integration of language

"Literature is language in which the various elements and components of the text are brought into a complex relation" (Culler, 1997,p.29). It deals with some elements of the literature, such as between sound and meaning, grammatical organization and thematic patterns. This relation will give an effect to the text for its whole, integration, harmony, tension and dissonance.

3. Literature as fiction

The utterances in literature have a special relation to the world. The relation is called 'fictional.' "The functionality of literature separates language from other contexts in which it might be used and leaves the work's relation to the world open to interpretation" (Culler, 1997,p.32)

4. Literature as aesthetic object The purpose of literature as an object is to give a range of effects but we cannot define it as a good literary work in general. It gives pleasure and contribution of its parts to the effect of the whole.

5. Literature as intertextual or self-reflexive construct

Literary works as literature can be related to other literary works. Here the literary works 
have intertextual other text. While self-reflexive construction consider to be a reflection of the community.

Furthermore Lazar (1993,p.

2-5) formulate the definition of literature as literary works, such as novels, short stories, plays and poems which are fictional and express messages of the texts and pay attention to the rich or uncommon

This paper has an aim to use the third approach that is learning through literature. Using role-play in teaching English, through literature that includes the assessment of the language teaching.

\section{Narrative}

"A narrative is a story whether told in prose or verse, involving events, characters, and what character say and do" (Abrams, 2009,p.208).

This paper offers narratives of Hodja as the literary text to conduct role-play method in teaching English through literature.

Literature and EFL (English-as-aForeign Language)

Literature provides authentic material. The learners are disclosed to actual language samples from real life and literature acts as a beneficial complement to such materials. Brumfit and Carter (1986,p.15) affirm the point that "a literary text is authentic text, real language in context, to which we can respond directly" (as cited in Yeasmin, et.al, 2011,p.285). Such a text securely grips the reader's imagination and makes scopes for the examination of the language as well.
Literature helps students develop interpretative abilities. Lazar (1993,p.19) says, "Literature is a particularly good source for developing students' abilities to infer meaning and to make interpretations. This is because literary texts are often rich in multiple levels of meaning, and demand that the reader/learner is actively involved in 'teasing out' the unstated implications and assumptions of the text."

For many university teachers of English as a foreign language (EFL), the study of literature is essential. Studying language through literature exposes students to meaningful contexts that are complete with descriptive language and interesting characters. The lessons that arranged in a wellstructured around the reading of literature introduces a reflective range of vocabulary, dialogues, and prose.

Over and above developing students' English language skills, through teaching literature also attracts to their imagination, develops cultural awareness, and encourages critical thinking about plots, themes, and characters. Most importantly, the activities that one can apply with literature lessons easily conform to the studentcentered and interactive tenets of Communicative Language Teaching (CLT).

\section{Literature as Appropriation}

Maley (2012, p. 303) offers three major approaches of to the use of literature in language teaching programs. They are: 
1. Literature as Study

In this context, the focus of the study is upon teaching about literature. It emphasizes on "telling" rather than on "discovery" and on memorizing content rather than on critical reflection and inquiry.

\section{Literature as Resource}

This approach tends to use literary text from wider range, and are used as samples of language or springboards into other language learning activities. This is characterized as teaching with literature.

\section{Literature as Appropriation}

Maleyhastermed the approaches above as literature from the outside in. While this approach has been termed by Maley as literature from the inside out. We may characterized this approach as learning through literature. Maley assumed that this approach is particularly appropriate in EIL context.

\section{Role-play}

Kolb, etc.(1995, p. 233)offera joyful teaching learning based on experiential learning. To create this method, there some conditionals of learning to be regarded:

1. Learning is a process, it is not the result

2. Learning is continuously process based on experience

3. Learning process needs problem solving of the conflicts in the world

4. Learning is a holistic process to adapt the world
5. Learning involves mutual relationship between individual and the environment

6. Learning is a process of creating knowledge.

Meanwhile, there are some selecting appropriate group techniques in teaching. Here are some techniques in teaching recommended by Brown (2007, p. 183-186); they are games, role-play and simulations, drama, projects, interview, brainstorming, information gap, jigsaw, problem solving and decision making, and opinion exchange. Role-play at least implicates two activities. It gives a role to one or more members of a group and assigns an objective or purpose that participants must accomplish.

Moreover, Lauber (2007, p. 186) states that in 1566 Alan Klein defined role play as "reality practice." Although role play doesn't work so well with knowledge, learners will develop skills in communication, approaches to conflict, managing meetings, and the like, with practice and feedback. Role play not only affords that kind of practice but also allows effective feedback, as well. Learners' attitudes turn as they obtain new perceptions about how reality works. These new perceptionslet them to sensitize themselves to others' ideas, sensibility, feelings, and values. Ethics training, which necessarily reaches inside into areas of values, usually concerns itself with what happens in the affective domain and provides rich opportunities for role play. 
Role-play is an effective way of learning in a normative and responsible attitude when the students meet problems. It frees students to be slightly creative in their linguistic output. In some versions, role-play allows rehearsal or practice time so that they can prepare what they are going to say. This process will give an effect of lowering students' anxiety. It also gives the students the opportunity to demonstrate how to use English in real life situations and makes them focus more on communication.

Role play can also be the assessment device. It can be the test takers to use discourse that might otherwise be difficult to elicit. With the prepared dialog, they can pretend to be another character. Role play can be controlled or guided by the teacher through technique takes testtakers beyond simple intensive and responsive levels to alevel of creativity and complexity that approaches real-world pragmatics. Scoring presents the usual issues in any task that elicits somewhat unpredictable responses from testtakers. The test administrator must determine the assessment objectives of the role play, then devise a scoring technique that appropriately pinpoints the objectives (Brown, 2004, p.174).

\section{Role-Play In Teaching English Literature \\ Principles for Role-play}

To have successful goal in teaching with this learning methods, there are principles for effective role play (Lauber, 2007, p. 190):

1. Attach the role play to a learning objectives
Each role-play should have a direct relation to the program of the class

2. Define the experience you want learners to have

It is because role playing is about the experience of practicing a skill or encountering a situation.

3. Make the roles as natural as possible

so that their mental energy frees up to focus on those steps or reacting to others' behaviors.

4. Build situations, note roles;

It is aimed to give the learners a place to start where they can ground on their existing knowledge or experience.

5. Create an observations checklist It should be five-to-eightnumber of items on an observers' checklist and the checklist should guide the observers in what behaviors and reactions to watch for.

6. Everyone has a role

Not every role will be a playing role, but each role must add to the experience and the learning objectives.

7. Give every role motivation It will create the problem behavior desired in the role. As the result, the role is humanized, with real issues and a level of complexity.

8. Role play, debrief, repeat

The best time to provide feedback is immediately after the skill being practiced is performed, and most role plays do that very well. Simply repeating the role play allows the learners to change gears and fix mistakes. In other words, 
after performing the first roleplay, trainer and learners debrief to see their first performance on videotape. Trainer gives feedback and allows the learner to practice and correct improper technique. Then the learner and actress repeat the roleplay,seeing improvements, gain confidence and believe what they have been learning.

9. Approximate work settings

The settings does not need to be placed in actual setting, but try to help the learners to set the setting closer to that feeling of the real work setting.

\section{Role-Play Variations}

The nine principles above can be applied to any approach to role play. The most common approaches to role play are "fishbowl" and "round robin" techniques (Lauber, 2007, p. 196-197).

\section{Fishbowl}

Role-play is the standard role-play approach, where some individuals perform a role-play and the others watch. This activity effects nerve to some individuals that are reluctant or shameful. Therefore, there are some techniques that exist to less the nerve-wracking for the players who feel they are performing for an audience:

1. Stage-as-simulator: set up the stage as closely as possible as the real-world workplace.

2. Rotating players: the players can be replace anytime when they get stuck on the stage. Everyone will be willing to take a turn.
3. Scripts: provide a written script to the role players. However if they do something wrong, it's because the script called for it.

4. Professional actors: hiring professional actor to act out a scripted scene for the observers to watch.

5. Trainer-takes-lead: it is a technique in which the trainer becomes the role player who is demonstrating the skills or attitudes to be learned. In this technique, the participants can play any other parts. The trainer also can stop frequently and asks for coaching from observers.

6. Triple-role-playing: this technique selects four learners for two parts. The first learners assume the first role and the others leave the room. They return one at a time while the supervisor delivering the review.

7. Role-play coaches: it is suggested that each role players have a coach with whom he or she can discuss the scenario before the role play. The coach also can give prompts to help the roleplayers during the activity.

8. Immediate feedback: this technique recommends raising hands, whistling, snapping, or clapping as possible prompts to give immediate feedback for the role players from the observers.

\section{Round-Robin}

This is the major role play approach, which the learners are divided into 
pairs, trios, quads, etc. and each group conducts a simultaneous role play. It means one scenario can be performed by some role players, because they switch roles and the role play is reenacted sequentially until the each learner has taken each role.

This role-play approach can be applied to other format of variations. The variation of the techniques includes stage-assimulator, scripts, professional actors, triple role playing, coaches, and immediate feedback.

\section{Procedure of Role-play}

Before designing a role-play, trainer should consider the resources available to trainer and learner. Then it should be decided on the amount of time trainer wish to present the exercise. Here are the steps for designing and implementing a roleplay (Manorom\& Pollock, 2006, p. 5):

\section{Design Process}

1. Determine the learning objectives of the role-play

The learning objectives can be theoretical as well as practical. In this paper, the writer will implement role-play to teach English for EFL through literature.

It is aimed at broadening students' comprehension on narratives of Hodja. First it develops reading skill, but then it also develops speaking skill. It is also to sensitize the learners to have new insights about how reality works.
2. Choose a scenario or situation from reality that highlights the key concepts of the course

By re-enacting events from reality students are able to deepen theirunderstanding of real life situations. Additionally readings and context about narratives of Hodja can beprovided from academic articles and documents relating tothe event.

3. Once you have selected a scenario you need to consider the various stakeholders and their perspectives and adapt the situation to the classroom

The learners are the students of center of language at UIN SunanKalijaga. They are students from five different study programs but from the same faculty. They are from Faculty of Tarbiyah and Education.

The students are divided in some groups of three randomly. The class consists of 30 students. It means there are 10 groups of three role players.

4. Plan the structure of your roleplay

This role-play will be taken for 2 times 100 minutes. However there are 2 times 100 minutes of time allocations for the students to read the narratives of Hodja and comprehend it. After comprehending the narratives, they should recreate the narrative into new form of genre, that is scenario or dialog (play). Here are the four stages to structure a role-play: 
a. Holding a briefing stage provides so that the students are familiar with their role in the role-play and the stage. They also should be familiar with the audience

b. Having interaction with other learners before the performance so that they can formulate relationship within the provided guidelines

c. Having a forum to communicate and negotiate about the format of the roleplay

d. Having debriefing to reconsider the learning objectives and answer the students' question in this session

5. Consider how you will assess your students

The students in this role-play will be assessed using rubric. Here is the rubric to assess the students' competence:

\begin{tabular}{|c|c|c|c|c|c|c|}
\hline & \multirow{2}{*}{$\begin{array}{l}\text { Aspects of } \\
\text { assessment }\end{array}$} & \multicolumn{3}{|c|}{ Score } & & \\
\hline & & 1 & 2 & 3 & 4 & 5 \\
\hline 1 & $\begin{array}{l}\text { Novelty in term of } \\
\text { theme }\end{array}$ & & & & & \\
\hline 2 & $\begin{array}{l}\text { Strength in term of } \\
\text { imagination }\end{array}$ & & & & & \\
\hline 3 & $\begin{array}{l}\text { Noveltyand strength } \\
\text { in term of characters }\end{array}$ & & & & & \\
\hline 4 & $\begin{array}{l}\text { Noveltyand strength } \\
\text { in term of plot }\end{array}$ & & & & & \\
\hline 5 & Coherence & & & & & \\
\hline 6 & $\begin{array}{l}\text { The smoothness of } \\
\text { performance }\end{array}$ & & & & & \\
\hline 7 & $\begin{array}{l}\text { The effectiveness of } \\
\text { style }\end{array}$ & & & & & \\
\hline 8 & $\begin{array}{l}\text { Teacher's affective } \\
\text { response }\end{array}$ & & & & & \\
\hline
\end{tabular}

6. The resources made available to students should assist them to participate in the role-play and fulfill their role. a. Generic resource that will give context to the role play

b. Specific resource that will relate to the role assigned to each student

c. Providing students with a guide to the role-play

\section{Implementation}

Here are some checklists that have to be existed in the implementation of role-play in four stages (Manorom\& Pollock, 2006, p. 7-9).

\section{Briefing Stage.}

a. Ensure students understand how the role play will work, especiallyhow they will interact with other players.

b. Explain the mode of interaction for each stage of the role-play.

c. Assign roles and distribute resources/reading materials accordingly.

d. Communicate deadlines for the first task (i.e. writing a description ofyour stakeholders' position, or approaching another stakeholder forsupport etc.)

\section{Interaction Stage.}

a. Allow students to interact with other players according to the roles andrelationships outlined in the background material (this may includepresenting a public stance in an online forum, building alliances withother stakeholders through letter writing, emails or private meetings,or lobbying other stakeholders).

b. As moderator you may introduce events through the 
medium ofcommunication (i.e. a news announcement) or take on the role of anew stakeholder to alter the course of interactions.

c. Check that all roles are active. If any students are not participating talkto them directly.

d. Monitor the interactions to ensure the roles are being playedaccordingly and that the learning environment is safe.

e. Identify learning opportunities when they arise and suggest furtherresources if necessary.

\section{Forum Stage}

a. Monitor the discussions as the forum progresses and intervene wheredeemed necessary. This may be to take on an unexpected role andenter negotiations or introduce problems, traps or new information tothe proceedings to challenge the students or engage students whoare not participating fully.

b. Monitor the interactions to ensure the roles are being playedaccordingly and that the learning environment is safe.

c. Identify learning opportunities when they arise and suggest furtherresources if necessary.

d. Assist students to bring the role play to a conclusion. A resolution maynot be possible and this can be discussed during the debriefing stage.

\section{Debriefing Stage}

Checklist to the stage:

a. Declare the role play officially over.

b. Discuss what happened in the role play. Place emphasis on drawingout underlying patterns and dynamics and how this affected whathappened.

c. Draw out the issues and concepts that were prominent in the roleplay and compare them to how the scenario developed in reality. What occurred in the role play that could not occur in reality and why?

d. Reflect on what was learnt from the role play, focussing not only onthe situation that was simulated but also the skills adopted bystudents during the role play to put their position across.

e. Evaluate the role play and get feedback from students on thetechnique.

\section{CONCLUSION}

The role-play is one of the methods in teaching language that has a special value. Role play not only affords that kind of practice but also allows effective feedback, as well. Learners' attitudes turn as they obtain new perceptions about how reality works. These new perceptions let them to sensitize themselves to others' ideas, sensibility, feelings, and values. Ethics training, which necessarily reaches inside into areas of values, usually concerns itself with what happens in the affective domain and provides rich 
opportunities for role play. It is an effective way of learning in a normative and responsible attitude when the students meet problems. It frees students to be slightly creative in their linguistic output.

In term of using role-play in English teaching through literature for EFL students, they will gain more ideas, sensibility, feelings and values. They also become more creative by creating the new product of genre in literary works. Their creativity can increase their linguistic competence, since the teacher's assessment will depend on their creativity in some novelty in term of theme, plot, characters, coherence and their affective response.

\section{REFERENCES}

Abrams, M.H. \&Harpham, G.G. (2009).Glossary of literary terms.Boston: Wadsworth Cengage Learning.

Brown, H. D. (2007). Teaching by principles: an integrative approach to language pedagogy ( $3^{\text {rd }}$ ed.). New York: Pearson Education, Inc.

Brumfit, C.J. \& Carter, R.A. (1986). "English Literature and English Language." In Brumfit and Carter (Eds.) Literature and Language Teaching (pp. 2-21). Oxford: Oxford University Press.

Culler, J. (1997).Literary theory: a very short introduction. New York: Oxford University Press.
Duff, A., \& Maley, A. (1990). Literature. Oxford: Oxford University Press.

Kolb, D.A., Osland, J.S., \& Rubin, I.M., (1995). Organizational Behavior: An Experiential Approach to Human Behaviorin Organizations. $\left(6^{\text {th }} \mathrm{ed}\right)$. Englewood Cliffs, NJ: Prentice Hall.

Lauber, Les. (2007). "Role Play: Principles to Increase Effectiveness" in Melvin L.Silberman (Ed.),The Handbook of Experiential Learning (pp. 185-201). San Fransisco, CA: John Wiley \& Sons, Inc.

Lazar, G. (2009) Literature and Language Teaching: A Guide for Teachers and Trainers. Cambridge:Cambridge University Press.

Maley, Alan.( 2012). Literature in Language Teaching. In Principle and Practices for Teaching English as an International Language. (pp. 299-317) New York \& London: Routledge Taylor \& Francis Group.

Manorom, K. \& Pollock, Z. (2006)."Role Play as a Teaching Method: A Practical Guide."Manual.The Mekong Learning Initiative and the MekongSub-region Social Research Centre, Faculty of Liberal Arts, UbonRatchathani University. 
McKay, S. (1982) "Literature in the ESL Classroom."TESOL Quarterly Vol. 16. No.4: 529536.

Paran, Amos (2008) "The role of literature in instructed foreign language learning and teaching: An evidence-based survey."Language Teaching, 41 (4), 465-496.

Yeasmin, $\quad$ N., Azad,Md. A.K.\&Ferdoush,J. (2011) "Teaching Through Literature: Designing Appropriate Classroom Activities." ASA University Review, Vol. 5 No. 2, JulyDecember, 283 - 297. 